\title{
A NOVEL OCCUPANT DETECTION-BASED VENTILATION CONTROL STRATEGY FOR SMART BUILDING APPLICATIONS
}

Cihan TURHAN* Energy Systems Engineering, ATILIM University, Turkey, cihan.turhan@atilim.edu.tr (iD) https://orcid.org/0000-0002-4248-431X)

Aydın Ege ÇETER Mechanical Engineering, ATILIM University, Turkey, ceter.egeaydin@student.atilim.edu.tr (iD https://orcid.org/0000-0002-1048-9642)

Received: 26.04.2021, Accepted: 06.09.2021

*Corresponding author

Research Article

DOI: $10.22531 /$ muglajsci.928315

\section{Abstract}

Traditional ventilation systems supply fresh air to the building on a consistent basis, however, do not ensure adequate comfortable areas in indoor environments. On the other hand, smart ventilation systems adjust indoor environment parameters optionally by occupancy schedules to provide desired indoor air quality while minimizing energy consumption. ASHRAE Standard 62, which shows ventilation strategies for acceptable indoor air quality, uses steady-state occupancy detection algorithms, however, dynamic methods are required behind simulation studies. To this aim, this study presents a dynamic novel ventilation control strategy by detecting occupants in an office building in Ankara-Turkey. The novel control strategy includes deployment of several sensors which measure carbon dioxide concentration, indoor air temperature and position of the door. A prototype of the controller is manufactured and tested in a real environment with the help of regulation of air flow in HVAC system. The proposed control strategy is tested between January $1^{\text {st }}, 2020$ and August $15^{\text {th }}$, 2020 and compared with traditional controller in terms of thermal comfort and energy consumption. The results showed that proposed controller decreased energy consumption by 16\% while satisfying thermal comfort for the $94 \%$ of total number of occupants.

Keywords: Occupant detection, Smart buildings, Ventilation systems, Indoor air quality, Door position

\section{AKILLI BİNA UYGULAMALARINDAKİ HAVALANDIRMA SISTEMI KONTROL STRATEJILERINDE KULLANICI SAYISI TESPITI TEMELLI YENI BIR YAKLAŞIM}

\begin{abstract}
Özet
Binalarda kullanılan geleneksel havalandırma sistemleri tutarlı bir șekilde ișlevini yerine getirmesine karșın, iç ortamda yeterli konforu sağlamamaktadır. Akıllı havalandırma sistemleri ise enerji tüketimini en aza indirirken, istenilen iç hava kalitesini sağlamak için iç ortam parametrelerini isteğe bağlı olarak kullanıcı sayısı tespiti ile ayarlamaktadır. Kabul edilebilir iç hava kalitesi için havalandırma gereksinimlerini düzenleyen ASHRAE 62 standardı, zamandan bağımsız kullanıcı sayısı tespit algoritmaları kullanmaktadır. Ancak bu tip simülasyon çalışmalarında dinamik metot ve algoritmaların kullanılması gerekmektedir. Bu amaç doğrultusunda, Ankara ATILIM Üniversitesi Mühendislik Fakültesi'nde yer alan bir ofis alanında, kullanıcı sayısı tespiti ile yeni bir dinamik havalandırma sistemi kontrol stratejisi geliştirilmiştir. Bu algoritma, karbondioksit konsantrasyonu, iç hava sıcaklığı ve kapı konumunu tespit eden bir dizi sensör yardımı ile elde edilmiştir. Üretilen prototip, HVAC sistemin hava akışını düzenlemektedir ve gerçek koşullarda test edilmiştir. Geliştirilen yeni yöntemin testleri 1 Ocak 2020 - 15 Ağustos 2020 tarihleri arasında yapılmış olup, termal konfor ve enerji tüketimi bağlamında geleneksel HVAC yönetim sistemi ile karşılaştırılmıştır. Elde edilen sonuçlara göre yeni kontrol stratejisi ve prototipin enerji tüketimini \%16 azalttığını, aynı zamanda kişilerin \%94'ünün ısıl konforu sağladığı tespit edilmiştir.
\end{abstract}

Anahtar Kelimeler: Kullanıcı sayısı tespiti, Akıllı bina sistemleri, Havalandırma sistemleri, İç hava kalitesi, Kapı pozisyonu Cite

Turhan, C., Çeter, A. E., (2021). “A Novel Occupant Detection-Based Ventilation Control Strategy for Smart Building Applications", Mugla Journal of Science and Technology, 7(2), 24-35. 


\section{Introduction}

Buildings are responsible of approximately $40 \%$ of the total energy consumption in Europe [1]. On the other hand, energy consumption of the buildings is expected to increase three times in 2050s compared to 2015 [2] Heating, Ventilating and Air-Conditioning (HVAC) systems consume $50 \%$ of the total energy share in office buildings [1]. Therefore, researchers aimed to reduce energy consumption rates and operate energy-efficient HVAC systems without affecting occupants' thermal comfort [3-5]. For developing energy-efficient HVAC systems, researchers focused on standard on/off and conventional Proportional-Integral-Derivative (PID) control systems in early 1980s. Nowadays, these control systems are called 'Traditional HVAC Control Systems'. However, traditional HVAC control systems have some significant limitations. First of all, controlling operational parameters of the traditional HVAC control systems is very problematic. These systems adjust and control only indoor air temperature of the environment. Absence of occupant detection and other parameters such as relative humidity and/or mean radiant temperature leads extra energy consumption and prevents the energy-efficient HVAC operations [6]. Reliable occupancy detection has a vital role on the effectiveness of HVAC systems [7]. Thereby, researchers concentrated on their studies on a new type of control strategy which is called "Occupant - centric Smart Control". To this aim, researches developed several occupancy detection methods to estimate number of occupancies with high accuracy. For instance, Ansanay-Alex [8] studied on an occupancy detection method based on Carbon dioxide $\left(\mathrm{CO}_{2}\right)$ concentration. However, this method could give inaccurate estimations due to the limitations such as situation of building or behavior of the occupants. On the other hand, Wang and Jin [9] developed a dynamic $\mathrm{CO}_{2}$ and outdoor air flow rate-based occupancy detection system. The authors found that $10 \%$ of total energy consumption of HVAC system could be saved by using dynamic ventilation rate instead of constant one. However, the control strategy was tested and evaluated only in a simulation programme. On the other hand, Cali et al. [10] studied the similar algorithm in Wang and Jin [9] and tried to estimate number of occupancies with $\mathrm{CO}_{2}$ concentration in order to determine ventilation strategy of the HVAC system. The developed algorithm detected the presence of the occupant with $96 \%$ of the time while the authors succeeded to estimate occupancy number correctly up to $81 \%$ of the total time. Besides the $\mathrm{CO}_{2}$ concentration, several parameters such as indoor air temperature and relative humidity, lighting level and occupants' motion can be used for occupancy detection. For instance, Hobson et al. [11] studied with $\mathrm{CO}_{2}$, motion sensors and light electricity load meters. Data obtained from the sensors were transferred via Wireless Fidelity (Wi-Fi) modules and used in order to detect exact occupant number. According to the results, researchers reached that the estimation success of Wi-Fi enabled devices are much better compared with ground truth counts with a correlation coefficient $\left(\mathrm{R}^{2}\right)$ of approximately $80-83 \%$. In addition, a novel occupancy detection system was developed by Candanedo and Feldheim [12] via using three different algorithms with $\mathrm{CO}_{2}$, temperature, humidity and light sensors to improve the accuracy of occupancy detection systems. The authors used Linear Discriminant Analysis (LDA), Classification and Regression Trees (CART) and Random Forest (RF) models and concluded that LDA model was able to predict the highest accuracy of $97 \%$ on occupancy detection. Masood et al. [13] developed an occupancy prediction system with the Extreme Learning Machines (ELM) algorithm by using similar sensors in [12]. Additionally, with the ELM algorithm, a faster learning process was provided compared to the ANN algorithm, and an accuracy of $81.37 \%$ was achieved in the occupancy estimation. However, position of the window and/or door has also a significant role for occupancy detection systems. Amayri et al. [14] brought a new perspective by their studies via using door/window position as well as other sensors which are counted above. The researchers benefitted from a machine learning algorithm which used if-then-else rules and concluded that the developed occupancy detection system estimated exact number of occupancies with an average estimation error of 0.19. Besides, Yang et al. $[15,16]$ used door position in addition to $\mathrm{CO}_{2}$ concentration, indoor air temperature and relative humidity, lighting and occupants' noise. It is worth to remind that surplus number of sensors and devices are given for occupancy prediction and detection [17].

Artificial Neural Network (ANN) is a data-driven predictor which simulates real biological system of human. The strategy learns from inputs and predicts outputs of a real system. ANNs can be used as a machine learning algorithm in order to predict occupancy number. For instance, Han et al. [18] decided to use dynamic ANN model which uses Time - Delayed Neural Network (TDNN) instead of commonly used static ANN models for conducting time-series analyzing. The authors used the $\mathrm{CO}_{2}$ as a parameter for occupancy prediction and additionally, dynamic neural network model provided delay for input values and output feedback that ensure time-series analyses. Likewise, Kim et al. [19] performed a long - term study and used various parameters including $\mathrm{CO}_{2}$ concentration for the purpose of occupancy number prediction. Researchers also compared Artificial Network (ANN), Classification and Regression Tree (CART) and Support Vector Machine (SVM) in their studies and obtained significant results. The authors proposed that occupancy prediction could be changed by an occupant with respect to certain times and seasons. In addition, the occupant modelbased energy simulations were very close to the real energy consumption measurements. 
Rahman and Han [20] studied with $\mathrm{CO}_{2}$ in order to predict occupancy number and compared ANN with Bayesian methods and tested performance in different conditions. On the other hand, a few studies are found on the usage of $\mathrm{CO}_{2}$ concentration, indoor air temperature and door position to predict occupancy number and operate HVAC ventilation system according to the results in the literature.

This paper aims to develop an accurate, reliable and energy-efficient HVAC control system without affecting occupants' thermal comfort in an office building. The rest of the paper is organized as follows. The next section describes in detail the different elements of the method including sensor data processing and structure of the predictor. Afterwards, the experimental setup and the results of a case study carried out in case building are presented. Finally, the authors conclude by summarizing the benefits and limitations of the novel control strategy and provide suggestions for improvements in future work.

\section{Methodology}

The methodology of the study splits into three main sections. Information about the case building is given in the first part. Afterwards, components and manufacturing process of the Occupancy Detection Device (ODD) is discussed in detail. Finally, third section represents the assessment methods of the study.

\subsection{Case Building}

The case building is located in Atılım University Faculty of Engineering in Gölbaşı/Ankara/Turkey, which is in Dsb climate zone according to the Köppen - Geiger Clime Classification [21,22] at latitude $39.81^{\circ} \mathrm{N}$ and longitude $32.72^{\circ} \mathrm{E}$ (Figure 1 ). The monthly average temperatures are usually $<15{ }^{\circ} \mathrm{C}$ and $>22{ }^{\circ} \mathrm{C}$ for winter and summer, respectively [23]. The heating period of the case building is from November to April.

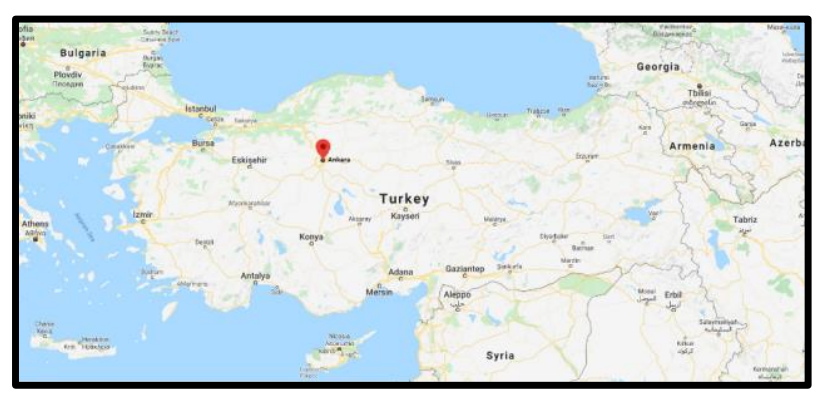

Figure 1. Location of the case building

The case building is a complex building which has nine floors with a standard PID control system. The experiments are conducted in an office room located in the $2^{\text {nd }}$ floor which faces to South-East direction (Figure 2 ). The office room has a total dimension of $4.7 \mathrm{~m}$ (width) x $3.25 \mathrm{~m}$ (depth) x $2.75 \mathrm{~m}$ (height) with three adiabatic walls (a, b and c) and one external wall (d) which has a 2.4 window to wall ratio (Figure 3 ). The internal door is made from wooden and has a dimension of $2.36 \mathrm{~m}$ (height) $\mathrm{x} 0.95 \mathrm{~m}$ (width). Table 1 depicts the characteristics of the case building elements.

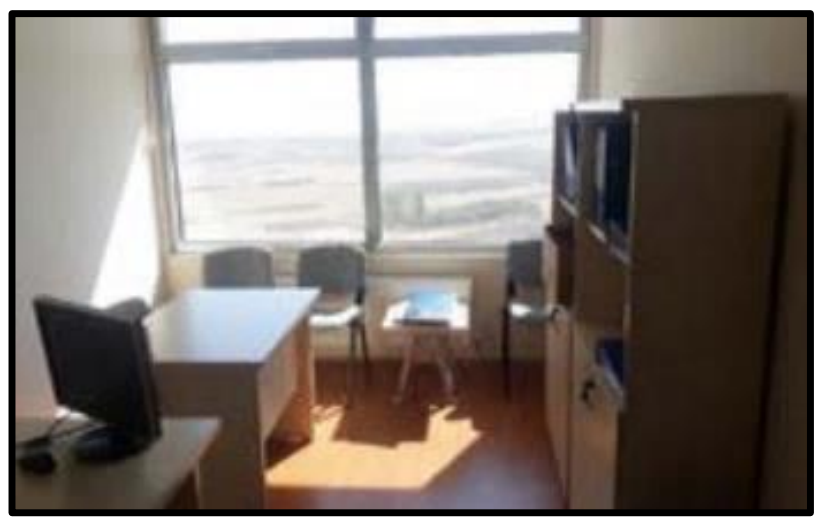

Figure 2. Image of the case building

Table 1. Thickness and heat transfer coefficients of building elements

\begin{tabular}{ccc}
\hline $\begin{array}{c}\text { Building } \\
\text { elements }\end{array}$ & Thickness(m) & $\begin{array}{c}\mathbf{U} \\
\text { value }\left(\mathbf{W} / \mathbf{m}^{2} \mathbf{K}\right)\end{array}$ \\
\hline $\begin{array}{c}\text { External } \\
\text { Wall }\end{array}$ & 0.25 & $2.86[24]$ \\
\hline $\begin{array}{c}\text { Window } \\
\text { (Aluminium } \\
\text { Frame) }\end{array}$ & $\begin{array}{c}0.07(6 \mathrm{~mm} \text { air } \\
\text { gap) }\end{array}$ & $4[24]$ \\
\hline $\begin{array}{c}\text { Door } \\
\text { (Wooden) }\end{array}$ & 0.04 & $2[24]$ \\
\hline
\end{tabular}

\subsection{Measurements}

For testing, Occupancy Detection Device (ODD), measurement campaign is conducted from $1^{\text {st }}$ of January, 2020 and $15^{\text {st }}$ of August, 2020 including heating and cooling seasons during office hours. The primary unit of the ODD measures indoor air temperature and $\mathrm{CO}_{2}$ concentration while auxiliary unit is used to understand the door position. Measurement campaign is performed in case of 5 different numbers of occupancy $(\mathrm{N}=1,2,3,4$, and 5) and 3 different door positions (Open, half - open and closed). Before each experiment, the office room is ventilated to ensure steady - state conditions for $\mathrm{CO}_{2}$ concentration and indoor air temperature levels. Thus, environmental effects under the same conditions are created for each day. The measurements are taken with 1 minute interval and lasts 3 hours for each situation (for instance, $\mathrm{N}=1$ and Open, $\mathrm{N}=2$ and Open, $\mathrm{N}=3$ and Closed etc.) in different days during the experiments. 


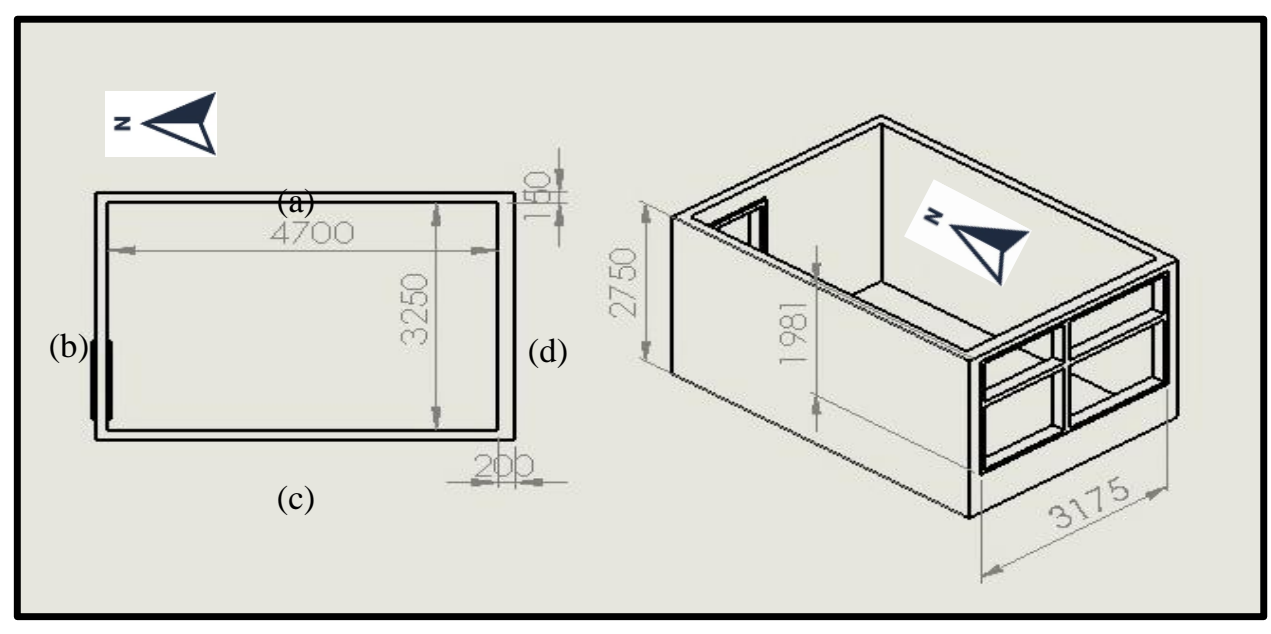

Figure 3. Technical drawings of the case building

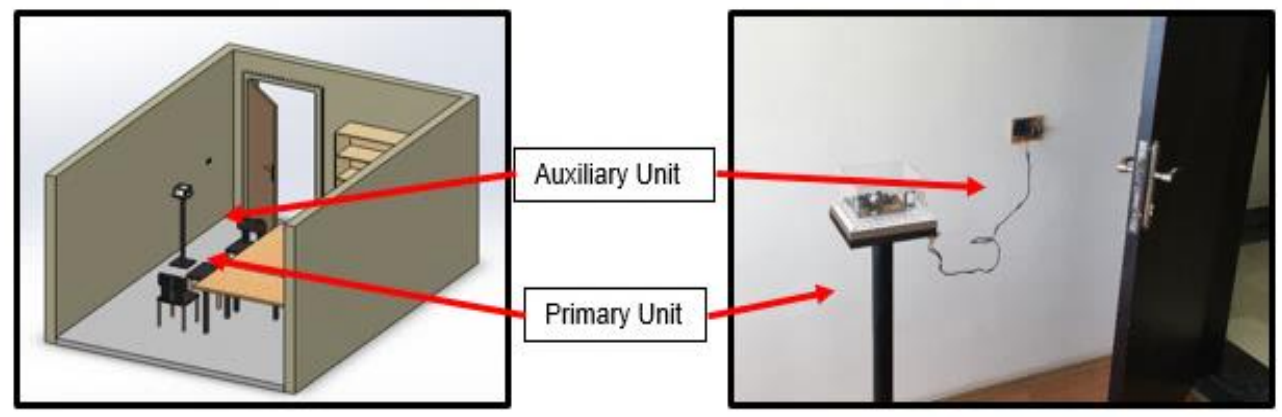

Figure 4. Location and units of ODD

\subsection{Development of ODD}

ODD is developed to estimate the occupancy number with a dynamic data - driven model and operated the HVAC system by regulating the air flow rate. Development of the ODD splits into two parts. In the first part, the development of the hardware is completed according to the system components and sensor networks. Afterwards, a dynamic data - driven model development is performed on Python with a measurement campaign.

\subsubsection{Hardware}

ODD uses multiple-sensors for estimating the number of occupancy and thus, ODD is produced as one primary module and one auxiliary module. The primary module of the device is constructed on a wood $(20 \mathrm{~mm} \times 19 \mathrm{~mm} \times$ $1.8 \mathrm{~mm}$ ) stage. Plexiglas is used to protect the circuit and sensors from external factors. The primary module of the device consists of one microcontroller (Arduino Mega), one $\mathrm{CO}_{2}$ concentration measurement sensor (MG811), and one temperature \& relative humidity sensor (DHT22).
Besides, the sensor (HC-SR04) of the auxiliary module is fixed to the edge of the primary module (Figure 6). Position of the primary unit is considered as an important case due to the sensing distance of the Ultrasonic Sensor and not to block the movement of the occupants. In addition, for providing $1.1 \mathrm{~m}$ height to primary module according to ASHRAE 55 Standard [25], the module is placed on a statue (Figure 4).

The auxiliary module of the device has a simpler structure. This module has a microcontroller (Arduino Uno) and an ultrasonic distance sensor (HC-SR04) on a perforated copper circuit plate. In addition, the other ultrasonic sensor, which is fixed to the edge of the primary module, connected with wires to the auxiliary module of the device (Figures 5 and 6).

Technical information about the sensors used in all modules is shown in Table 2. 


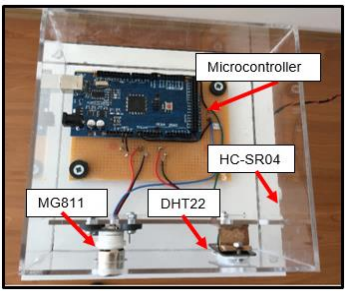

Figure 1. Primary Unit of ODD

Table 2. Specification of the sensors

\begin{tabular}{|c|c|c|c|c|}
\hline \multirow[b]{2}{*}{ Sensors } & \multirow{2}{*}{$\begin{array}{l}\text { Sensor } \\
\text { Types }\end{array}$} & \multirow{2}{*}{$\begin{array}{c}\text { Aim of } \\
\text { Usage }\end{array}$} & \multicolumn{2}{|c|}{ Specifications } \\
\hline & & & $\begin{array}{l}\text { Measurement } \\
\text { Range }\end{array}$ & Sensitivity \\
\hline & $\begin{array}{c}\text { MG } 811 \\
{[26]}\end{array}$ & $\begin{array}{c}\text { Carbon } \\
\text { dioxide } \\
\text { Concentra } \\
\text { tion }\end{array}$ & $\begin{array}{c}350-10000 \\
\text { ppm }\end{array}$ & $\pm 20 \mathrm{ppm}$ \\
\hline 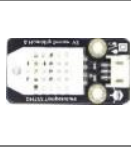 & $\begin{array}{c}\text { DHT } 22 \\
\text { [27] }\end{array}$ & $\begin{array}{l}\text { Temperat } \\
\text { ure and } \\
\text { Relative } \\
\text { Humidity }\end{array}$ & $\begin{array}{c}\mathrm{T}:-40-80{ }^{\circ} \mathrm{C} \\
\text { RH: } 0-100 \% \\
\text { RH }\end{array}$ & $\begin{array}{l}\mathrm{T}:< \pm 1{ }^{\circ} \mathrm{C} \\
\mathrm{RH}: \pm 3 \%\end{array}$ \\
\hline & $\begin{array}{c}\mathrm{HC}- \\
\mathrm{SR04} \\
{[28]}\end{array}$ & $\begin{array}{l}\text { Distance } \\
\text { and Door } \\
\text { Position }\end{array}$ & $2 \mathrm{~cm}-400 \mathrm{~cm}$ & $\pm 0.1 \mathrm{~cm}$ \\
\hline
\end{tabular}

\subsubsection{Software}

After the development of the circuit and hardware processes, a computer program is written for performing the ODD. The ODD uses Python - based software language with separate codes between sensors. In the primary module, software for MG811 and DHT22 are combined with each other and embedded into the Arduino Mega. Besides, same software development process is performed for the auxiliary module and embedded into the Arduino Uno as in the primary module.

The auxiliary module of the ODD uses a matrix system for the determination process and based on an algorithm that sensing the existence of the door by each ultrasonic sensor and decide the position of the door by using algorithm in Equations in Figure 7.
Ultrasonic Sensor 1 and Ultrasonic Sensor 2 represents the sensors located on the wall and fixed on the edge of the primary unit, respectively. Since a single sensor detects the door, sends to the microcontroller a digital signal output of " 1 " in contrast of this, a digital signal output of " 0 ". Position of the door determined by the combination sensor output conditions.

For each situation and door position, the values of ' 0.01 ', '0.5' and '0.99' is used by ODD for predict number of occupancies in order to avoid confusion in ANN model.

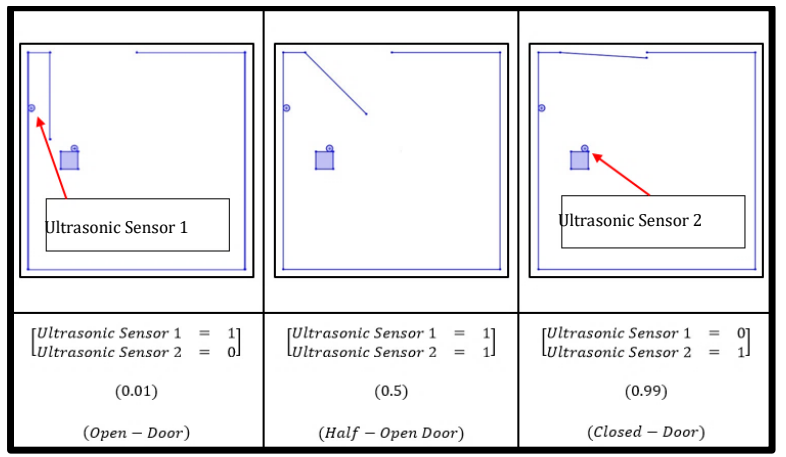

Figure 7. Representation of door position determination process

The ODD uses Artificial Neural Network (ANN) in order to predict occupant number inside the case building. ANNs are non-linear and data-driven predictor models which uses input-output pairs for training [29]. The model is an alternative technology of conventional regression models by catching complex and non-linear relationships among parameters. The structure of the ANN consists of three layers namely; input, hidden and output layers (Figure 8). Input layer introduces real data to the model while output layer computes predictions. Hidden layer connects input and output layers by optimized interconnection weights.

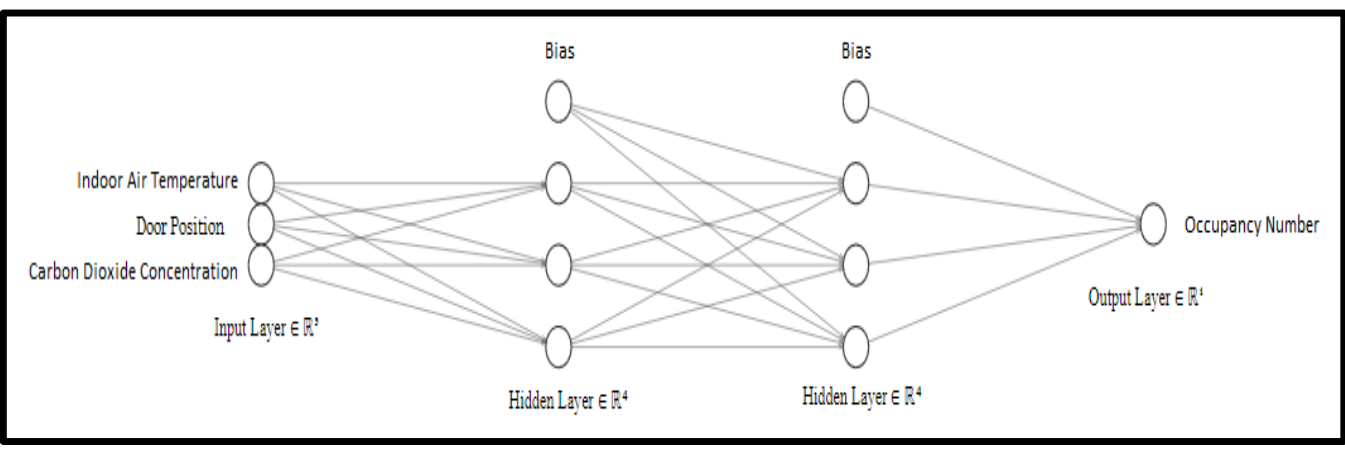

Figure 8. Artificial neural network structure of predictor 
In this study, a novel Python code-based computer programme which is developed by one of the authors is used to implement ANN. Inputs are selected as indoor air temperature, door position and $\mathrm{CO}_{2}$ concentration data which are obtained in-situ measurements of the ODD device. Output parameter is designed as the occupancy number. The ANN model is trained with 21.219 data by 20.000 iterations. $80 \%$ of the total data is used for training stage while the rest is released for testing of the developed model. Levenberg-Marquard (LM) training algorithm is used while bias terms are also included in the model. The learning rate is chosen as 0.1 while optimal hidden layer number is found as 2 with three neurons for each. Figure 9 depicts the block diagram of novel Occupancy-Based HVAC control system.

The result of the ANN model, then, is sent to the HVAC system model with the help of data acquisition systems in order to regulate air-flow rate. HVAC characteristics and Transfer Function of HVAC model is derived from Turhan et al. [30] and adapted to occupancy - based airflow regulation of a real HVAC system. According to the system design, on the testing process, $\mathrm{CO}_{2}$ concentration, indoor air temperature, and door position data enter to the MATLAB ${ }^{\circledR}$ block diagram [31].

The number of occupancy value, which is a constant output of ANN model, evaluated by round operator, and an accurate estimation made by rounding this number to the closest integer. Estimated number of occupancy value sent to the PID controller of existing HVAC system. Hereafter, the PID controller calculates error and transfers the number of occupancy value to the HVAC system [30]. According to the ASHRAE 62.1 [5] Table 6.2.2.1-Minimum Ventilation Rates in Breathing Zone, air-flow rate of ODD is calculated per each occupant according to the Eq.1.

$$
V_{b z}=R_{p} x P_{z}+R_{a} x A_{z}
$$

In Eq.1, $\mathrm{V}_{\mathrm{bz}}$ depicts breathing zone air-flow in $\mathrm{m}^{3} / \mathrm{h}, \mathrm{R}_{\mathrm{p}}$ is air-flow rate per person (L/s.person), $P_{z}$ refers zone population (number of person), $\mathrm{R}_{\mathrm{a}}$ is required air-flow rate per unit area $\left(\mathrm{L} / \mathrm{s} \cdot \mathrm{m}^{2}\right)$ and finally $A_{z}$ represents total zone area $\left(\mathrm{m}^{2}\right)$. Table 3 summarizes the air flow rates of existing HVAC system and ODD, respectively. In the calculations, the peak of occupancy is selected as 5 since EN 15251 and EN 16798 give the default occupant density as $10 \mathrm{~m}^{2} /$ person for a single office [32,33]. Firstly, the occupancy number is estimated from the ANN model which is existed in the ODD controller, then, the ODD uses Eq.1 for determining the air-flow rate for the building according to the estimated occupancy number.

Finally, it is worth to note that the total price of ODD system is around $114 \$$.

\subsection{Assessments}

The tests were conducted in two office rooms with similar architectural configurations. One office is controlled with the PID controller while another is controlled with the ODD controller. For the purpose of evaluating performance and accuracy of the ODD, the testing stage was performed between $1^{\text {st }}$ of January, 2020 and $15^{\text {st }}$ of August, 2020 including heating and cooling seasons. During the testing stage, the ODD and HVAC system were operated and data from the experiment setup was collected and was used for comparing the performance of the ODD with standard PID controller. On the other hand, total energy consumption of the HVAC system is analyzed with a three phase-power analyzer in $\mathrm{kWh}$. EXTECH 3-phase power analyzer which has $\pm 2 \%$ $\mathrm{kWh}$ accuracy is used to measure energy consumption. On the other hand, thermal comfort of the occupants is obtained from a developed mobile application developed in [6]. The occupants use mobile application in every 10 minutes and the results are stored in a web-server of ODD (Figure 11).

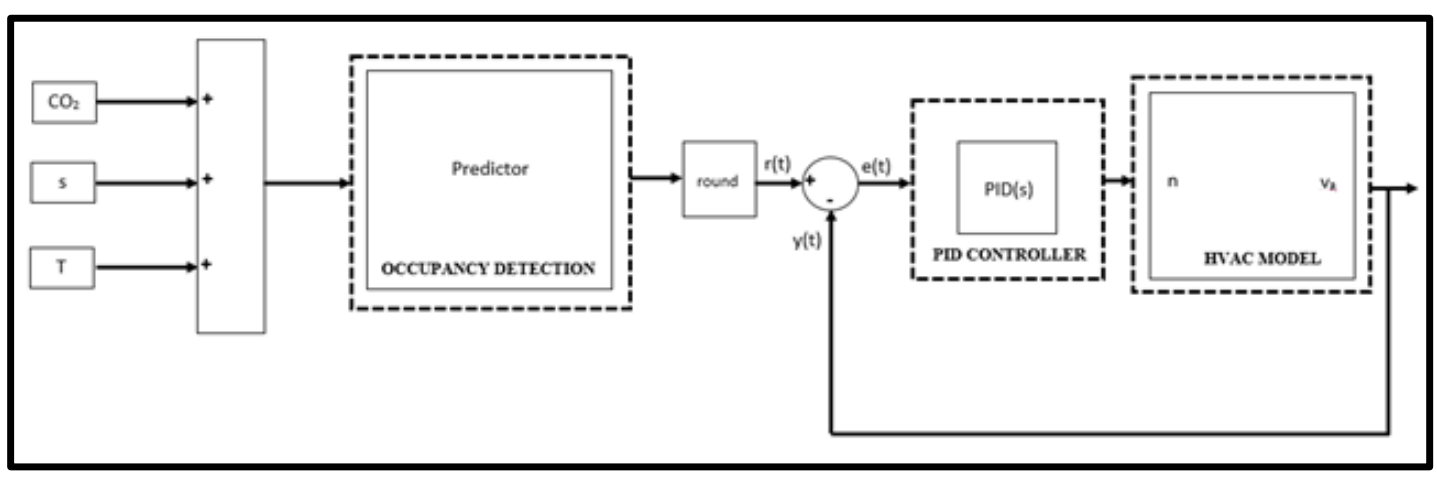

Figure 3. Block diagram of occupancy - based HVAC control system 


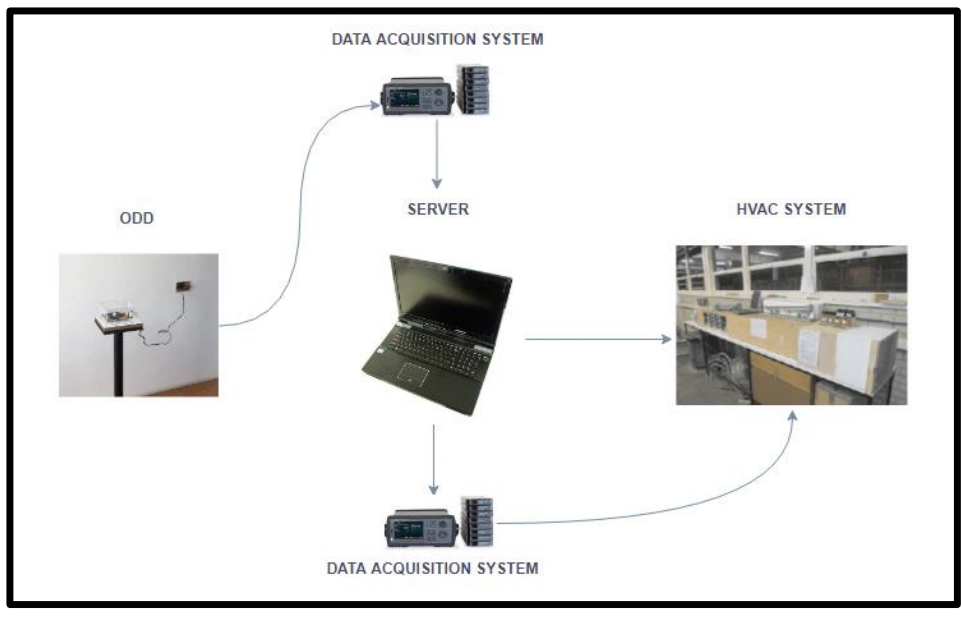

Figure 4. HVAC control system with ODD

Table 3. Comparison of air-flow rates between existing system and ODD

\begin{tabular}{|c|c|c|c|}
\hline & $\begin{array}{l}\text { HVAC system } \\
\text { with PID } \\
\text { controller* }\end{array}$ & $\begin{array}{l}\text { Number of } \\
\text { Occupancy }\end{array}$ & ODD** \\
\hline \multirow{6}{*}{$\begin{array}{l}\text { Air-flow } \\
\text { rate } \\
\left(\mathrm{m}^{3} / \mathrm{h}\right)\end{array}$} & \multirow[t]{2}{*}{ Level 1= 180} & 0 & 0 \\
\hline & & 1 & 102 \\
\hline & \multirow{2}{*}{ Level $2=220$} & 2 & 138 \\
\hline & & 3 & 174 \\
\hline & \multirow[b]{2}{*}{ Level 3= 260} & 4 & 210 \\
\hline & & 5 & 246 \\
\hline
\end{tabular}

*Existing HVAC system uses three-levels of air flow rate

** ODD regulates HVAC system according to the ventilation rates adapted from ASHRAE 62.1 for office zone.

It is worth to note that using mobile application merely lasts 2 seconds. Therefore, 2 seconds does not cause the labor loss for the occupants. Furthermore, there were the occupants who did not use mobile application for every 10 minutes. This time, the data is removed from the analysis. During the operations of both PID system and ODD device, the thermal comfort of the occupants is collected as Actual Mean Vote (AMV) according to the ASHRAE 55 Standard [25]. AMV values refers a thermal scale which runs from cold $(-3)$ to hot $(+3)$. 0 value of $\mathrm{AMV}$ is accepted as neutral with a tolerance of $\pm 0.5 \mathrm{AMV}$. More information on AMV and mobile application can be found in [6].

In order to evaluate the performance of predictor, two metrics are employed for the study: Coefficient of Determination $\left(\mathrm{R}^{2}\right)$ and Normalized Root Mean Squared Error (NRMSE) which are defined as Eqs. 2 and 3. High $\mathrm{R}^{2}$ and low NRMSE values ensure that the model is accurate.

$$
\begin{array}{r}
R^{2}=1-\frac{\sum_{i}\left(t_{i}-o_{i}\right)^{2}}{\sum_{i}\left(o_{\dot{\mathrm{I}}}\right)^{2}} \\
N R M S E=\frac{\sqrt{\sum_{i=1}^{n} \frac{\left(t_{i}-o_{i}\right)^{2}}{n}}}{d_{\max }-d_{\min }}
\end{array}
$$

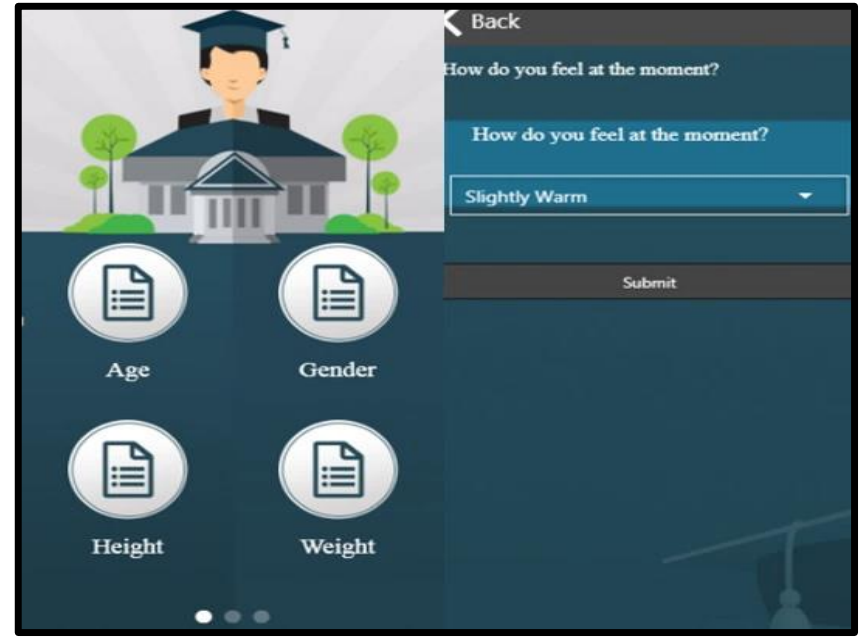

Figure 11. Developed mobile application to obtain thermal comfort of occupants

Where $\mathrm{o}_{\mathrm{i}}$ represents the observed value for $\mathrm{i}^{\mathrm{i} \text { th }}$ data. Besides, $t_{i}, \mathrm{~d}_{\max }$ and $\mathrm{d}_{\min }$ refer to predicted value of data for observation i, maximum and minimum values of data, respectively. Additionally, it is worth to say that $n$ represents the total number of data.

\section{Results and Discussions}

While HVAC system is operated at three levels of air-flow rate with PID control, ODD regulates air-flow rate of HVAC system according to the estimated occupancy number (Table 3). To test ODD and compare with existing PID control system, a measurement campaign is designed between $1^{\text {st }}$ of January, 2020 and 15 ${ }^{\text {th }}$ of August, 2020.

\subsection{ANN Model Results}

The aim of ANN model in this study is to predict occupancy number from in-situ measurements. A total of 21.219 data is included to train and validate the ANN model. \%80 of the total data is used for training of the model while the rest is testing. The ANN model generates occupancy number with an accuracy of $91 \%$ of $\mathrm{R}^{2}$ with a normalized root mean square error of $10.1 \%$. The results indicate that ANN model has strong correlation to estimate occupancy in the case study building. Figure 12 depicts the result of ANN output compared with real data for a typical day for each month as an example. It is worth to note that the model sometimes estimates data which are not identical with the real data. The reason could be the heterogonous distribution of body mass indices of occupants. Different occupants produce different $\mathrm{CO}_{2}$ concentrations and internal heat gains to the environment. Thus, parameters such as indoor air temperature and $\mathrm{CO}_{2}$ concentrations are highly affected from occupant diversity. However, in summary, the ANN 
model successfully estimates occupancy number in the case building.

Table 4 represents indoor environmental data with respect to door location. It is worth to remind that $\mathrm{CO}_{2}$ concentration and indoor air temperature are decreasing with lower "s" values. Therefore, the ODD captures the occupancy data with interoperating non-linear relationships among parameters.

Table 4. Door location data with respect to environmental parameters

\begin{tabular}{|c|c|c|}
\hline $\mathbf{N}=\mathbf{1}$ & $\begin{array}{c}\text { Temperature } \\
\left({ }^{\circ} \mathrm{C}\right)\end{array}$ & $\begin{array}{c}\mathrm{CO}_{2} \text { Concentration } \\
(\mathrm{ppm})\end{array}$ \\
\hline$s=0.01$ & 24.90 & 574 \\
\hline$s=0.5$ & 26.10 & 668 \\
\hline$s=0.99$ & 27.30 & 966 \\
\hline $\mathbf{N}=2$ & $\begin{array}{c}\text { Temperature } \\
\left({ }^{\circ} \mathrm{C}\right)\end{array}$ & $\begin{array}{c}\mathrm{CO}_{2} \text { Concentration } \\
(\mathrm{ppm})\end{array}$ \\
\hline$s=0.01$ & 27.60 & 725 \\
\hline $\mathrm{s}=0.5$ & 28.10 & 818 \\
\hline$s=0.99$ & 29.70 & 4506 \\
\hline $\mathbf{N}=\mathbf{3}$ & $\begin{array}{c}\text { Temperature } \\
\left({ }^{\circ} \mathrm{C}\right)\end{array}$ & $\begin{array}{c}\mathrm{CO}_{2} \text { Concentration } \\
(\mathrm{ppm})\end{array}$ \\
\hline$s=0.01$ & 28.70 & 942 \\
\hline$s=0.5$ & 29.10 & 1021 \\
\hline$s=0.99$ & 31.10 & 8242 \\
\hline $\mathbf{N}=4$ & $\begin{array}{c}\text { Temperature } \\
\left({ }^{\circ} \mathrm{C}\right)\end{array}$ & $\begin{array}{c}\mathrm{CO}_{2} \text { Concentration } \\
(\mathrm{ppm})\end{array}$ \\
\hline$s=0.01$ & 30.80 & 1072 \\
\hline $\mathrm{s}=0.5$ & 32.40 & 1186 \\
\hline$s=0.99$ & 33.10 & 8644 \\
\hline $\mathbf{N}=\mathbf{5}$ & $\begin{array}{c}\text { Temperature } \\
\left({ }^{\circ} \mathrm{C}\right)\end{array}$ & $\begin{array}{c}\mathrm{CO}_{2} \text { Concentration } \\
(\mathrm{ppm})\end{array}$ \\
\hline$s=0.01$ & 32.20 & 1193 \\
\hline$s=0.5$ & 34.60 & 1336 \\
\hline$s=0.99$ & 34.70 & 9183 \\
\hline
\end{tabular}

\subsection{Energy Consumption Results}

Figure 13 gives energy consumption of PID controller and ODD with respect to heating and cooling seasons. Total energy consumption for almost 6 months is 1334 $\mathrm{kWh}$ for PID controller and $1121 \mathrm{kWh}$ for the ODD. The usage of the ODD decreases energy consumption by $11 \%$ and $20 \%$ for cooling and heating seasons, respectively, compared to the existing PID controller of HVAC system. Finally, it is worth to remind that total energy consumption is decreased by $16 \%$ compared to the PID control strategy. Considering the seasons, energy savings are higher in the heating season than cooling period. One of the reasons could be the location of case building which has hot and humid summers but cold winters.
Another reason is that occupants prefer to open internal door in summer which results in an increase on energy consumption of the ODD. The $\mathrm{CO}_{2}$ concentration and indoor air temperature never changes since the door faces internal zones. Thus, the accuracy of the model is decreasing in cooling periods.

\subsection{Thermal Comfort Results}

Figure 14 depicts the comparison of AMV values for PID controller and ODD for the total measurement days. It is worth to remind that ASHRAE 55 accepts the range of $\pm 0.5 \mathrm{AMV}$ as comfortable zone (light blue zone in the figure). The black line depicts the average AMV values of occupants per day while the ODD is operated. On the other hand, red line represents the average AMV values of occupants per day of existing PID controller.

With the operation of existing PID controller, the average thermal comfort of occupants remains in comfort zone in only $21 \%$ of the total measurement days while it never satisfies neutral thermal comfort which is 0 of AMV value. On the other hand, the average AMV values of occupants are in comfort zone in $94 \%$ of the total measurement days with the operation of the ODD. Additionally, occupants feel neutral thermal comfort in $24 \%$ of the total days.

Table 5 represents the percentage of the days which the occupants stay in the comfort range $( \pm 0.5$ AMV $)$ compared to the total measurement days with respect to the seasons. Considering the seasons, thermal comfort of the occupants in the heating season are higher than the cooling season for both controllers. One reason could be the occupant's thermal perception and the adaptation to the climate since the case building is located in Dsb climate zone. Therefore, the occupants prefer lower temperatures in winter.

Past studies showed that overly-excessive ventilation rates have little advantageous to the occupant's thermal comfort, thus, well-ventilated buildings (e.g., above 36 $\mathrm{m}^{3} / \mathrm{h}$ per occupant) were associated with detecting real number of occupancies [34]. Moreover, there should be an optimal balance between energy consumption and thermal comfort. Further experiments are required for optimization of these two factors.

The results of this study indicate that the ODD achieves better thermal comfort while decreasing energy consumption of the HVAC system compared to the traditional ventilation control methods. However, the ODD is a device which merely estimates occupant number from environmental data in a specific zone and regulates ventilation rate of the HVAC system. It is worth to note that adaptive behaviors of the occupants could also affect thermal comfort and energy consumption of the buildings. To this aim, more input parameters should be included in such systems. 

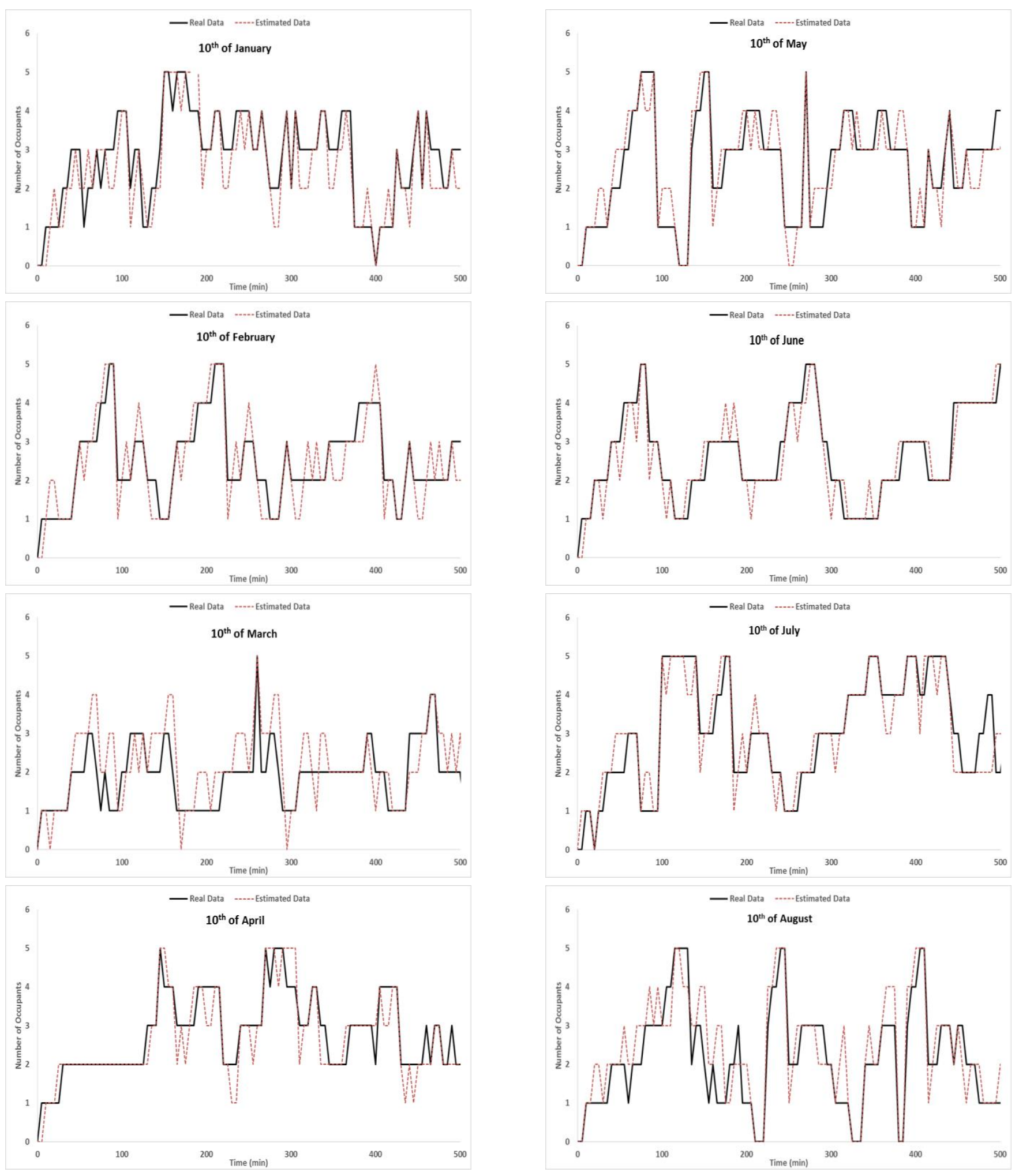

Figure 5. Occupancy prediction results for a typical day for each month 


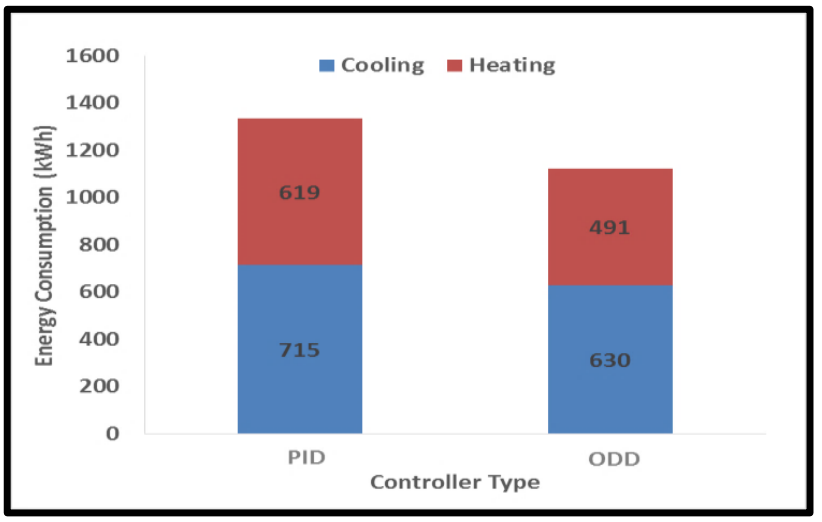

Figure 13. Comparison of energy consumption of PID controller and ODD

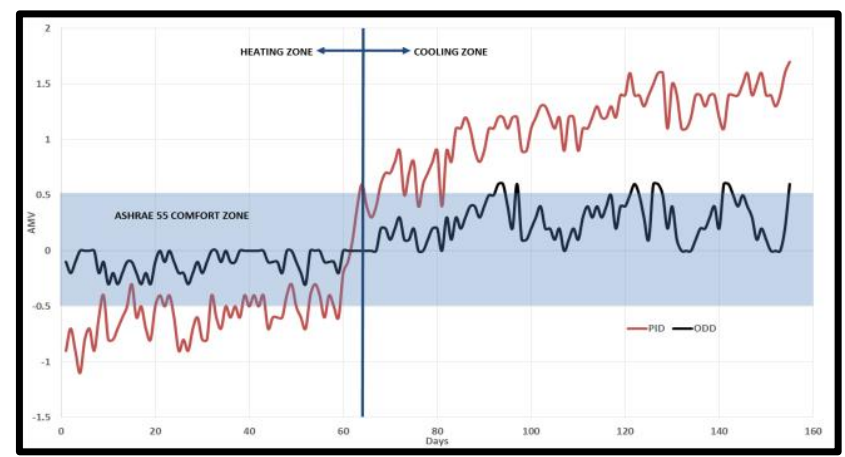

Figure 6. Comparison of thermal comfort of occupants with PID controller and ODD

Table 5 Summary of the thermal comfort ranges for both controller

\begin{tabular}{cccc}
\hline \multirow{2}{*}{$\begin{array}{c}\text { Controller } \\
\text { Type }\end{array}$} & \multicolumn{3}{c}{ Comfort Range $( \pm \mathbf{0 . 5}$ AMV) $(\mathbf{\%})$} \\
\cline { 2 - 4 } PID & Heating & Cooling & Total \\
\hline ODD & 28 & 5 & 21 \\
\hline
\end{tabular}

\section{Uncertainty Analysis}

A further study was considered in order to analyze the reliability and robustness characteristics of the ODD controller. Monte-Carlo method, which depends on measurement errors due to the accuracy of the sensors, was used for the uncertainty analysis [35]. The mean values were selected as an average case while the accuracies of the sensors were used as minimum and maximum values of the corresponding parameter values for each measurement. Table 6 represents the method results in terms of energy consumption (kWh) for the ODD and PID controllers.

On the basis of the results, the PID controller still consumed more energy than the developed ODD controller under the experiments with measurement errors. This result showed that the ODD lead to the best performance when model of the controller and measurement disturbances were taken into account.

Table 6. Monte-Carlo analysis results

\begin{tabular}{cccc}
\hline $\begin{array}{c}\text { Controller } \\
\text { Type }\end{array}$ & $\begin{array}{c}\text { Minimum } \\
\text { (kWh) }\end{array}$ & $\begin{array}{c}\text { Average } \\
\text { (kWh) }\end{array}$ & $\begin{array}{c}\text { Maximum } \\
\mathbf{( k W h )}\end{array}$ \\
\hline PID & 1229 & 1334 & 1351 \\
ODD & 1003 & 1121 & 1195 \\
\hline
\end{tabular}

\section{Conclusions and Future Works}

This study aims to develop a novel ventilation control strategy via an occupant detection device (ODD) which uses $\mathrm{CO}_{2}$ concentration, indoor air temperature and door position as inputs of the predictor. Artificial Neural Network is selected as a predictor in order to ensure occupancy number in a case building. The results shows that novel ventilation control strategy (ODD) can be used in order to predict occupancy number and save energy while maintaining thermal comfort of occupants.

The ODD uses ANN with 3 inputs. Except the position of the door, environmental parameters can be easily measured with objective sensors. The number of parameters could be increased in order to improve accuracy of the predictor. In addition, larger data numbers are required to increase the accuracy.

Human-building interaction (e.g., use of thermostats) is a vital issue for smart buildings, however, there should be automation on counting occupancy while utilizing data from the environment. Considering the countries who have large building stocks like Turkey, occupant-centric control devices like ODD can be useful for both new and existing buildings. Thus, more comfortable zones can be achieved with a significant number of energy savings.

This study is an example of occupant detection device which uses ANN as machine learning system. Future work will develop control logic from other prediction models such as Fuzzy Logic and Model Predictive Controller and implement a control method in a realworld HVAC system to quantify a significant number of energy saving. Furthermore, the strategy of the ODD should be further studied for different building types.

\section{References}

[1] N. Payam, J. Fatemeh, M. T. Mohammad, G. Mohammad, and M. A. Muhd Zaimi, "A global review ofenergy consumption, $\mathrm{CO}_{2}$ emissions and policy in the residential sector (with an overview of the top tenCO2emitting countries)," Renewable and Sustainable Energy Reviews, 43, 843-862, 2015.

[2] Singh, S. and Kennedy, C., "Estimating future energy use and $\mathrm{CO}_{2}$ emissions of the world's cities", Environmental Pollution, 203, 271-278, 2015. 
[3] Escriva-Escriva, G., Segura-Heras, I. and AlcazarOrtega, M., "Application of an energy management and control system to assess the potential of different control strategies in HVAC systems", Energy and Buildings, 42(11), 2258-2267, 2010.

[4] Rashid, S. A., Haider, Z., Hossain, S. M. C., Memon, K., Panhwar, F., Mbogba, M. K., Hu, P. and Zhao, G., "Retrofitting low-cost heating ventilation and airconditioning systems for energy management in buildings", Applied Energy, 236, 648-661, 2019.

[5] American Society of Heating, Refrigerating and AirConditioning Engineers, 2019. Ventilation for Acceptable Indoor Air Quality (Standard 62.1). Atlanta, GA: ASHRAE.

[6] Turhan, C., "Development of Energy Efficient Personalized Thermal Comfort Driven Control in HVAC Systems", (PhD Thesis), Izmir Institute of Technology, İzmir, 127, 2018.

[7] Yang, Z. and Becerik-Gerber, B., "The coupled effects of personalized occupancy profile-based HVAC schedules and room reassignment on building energy use", Energy and Buildings, 78, 113-122, 2014.

[8] Ansanay-Alex, G., "Estimating Occupancy Using Indoor Carbon Dioxide Concentrations Only in an Office Building: a Method and Qualitative Assessment", In: 11th REHVA World Congress "Energy efficient, smart and healthy buildings": Clima, Prague, June 2013.

[9] Wang, S. W. and Jin, X. Q., " $\mathrm{CO}_{2}$-based occupancy detection for on-line outdoor air flow control", Indoor and Built Environment, 7(3), 165-181, 1998.

[10] Cali, D., Matthes, P., Huchtmann, K., Streblow, R. and Muller, D., " $\mathrm{CO}_{2}$ based occupancy detection algorithm: Experimental analysis and validation for office and residential buildings", Building and Environment, 86, 39$49,2015$.

[11] Hobson, B. W., Lowcay, D., Gunay, H. B., Ashouri, A. and Newsham, G. R., "Opportunistic occupancy-count estimation using sensor fusion: A case study", Building and Environment, 159, 106154, 2019.

[12] Candenedo, L. M. and Feldheim, V., "Accurate occupancy detection of an office room from light, temperature, humidity and $\mathrm{CO}_{2}$ measurements using statistical learning models", Energy and Buildings, 112, 28-39, 2016.

[13] Masood, M. K., Soh, Y. C. and Chang, V. W. C., 2015. "Real-time occupancy estimation using environmental parameters", In: International Joint Conference on Neural Networks, Killarney, Ireland on 12-17 July 2015.

[14] Amayri, M., Arora, A., Ploix, S., Bandhyopadyay, S., Ngo, Q. D. and Badarla, V. R., "Estimating occupancy in heterogeneous sensor environment", Energy and Buildings, 129, 46-58, 2016.

[15] Yang, Z., Li, N., Becerik-Gerber, B. and Orosz, M., “A systematic approach to occupancy modelling in ambient sensor-rich buildings"," Simulation-Transactions of the Society for Modelling and Simulation International, 90(8), 960-977, 2014.

[16] Yang, Z., Li, N., Becerik-Gerber, B. and Orosz, M., "A Non-Intrusive Occupancy Monitoring System for Demand Driven HVAC Operations" In: Construction Research Congress, West Lafayette, Indiana, United States on 21-23 May 2012, 828-837.

[17] Abade, B., Perez Abreu, D. and Curado, M., “A NonIntrusive Approach for Indoor Occupancy Detection in Smart Environments", Sensors (Basel), 18(11):3953, 2018.

[18] Han, H., Jang K., Han, C. and Lee, J., “Occupancy Estimation Based On $\mathrm{CO}_{2}$ Concentration Using Dynamic Neural Network Model", In: AIVC34, Athens, Greece on 25-26 September 2013, 443-450.

[19] Kim, S., Song, Y., Sung, Y. and Seo, D., “Development of a Consecutive Occupancy Estimation Framework for Improving the Energy Demand Prediction Performance of Building Energy Modelling Tools", Energies, 12(3), 433, 2019.

[20] Rahman, H. and Han, H., "Bayesian estimation of occupancy distribution in a multi-room office building based on $\mathrm{CO}_{2}$ concentrations", Building Simulation, 11, 575-583, 2018.

[21] http://koeppen-geiger.vu-wien.ac.at/present.htm (05.04.2020)

[22] Yılmaz, E. and Çiçek, İ. “Detailed Köppen-Geiger climate regions of Turkey - Türkiye'nin detaylandırılmış Köppen-Geiger iklim bölgeleri", Journal of Human Sciences, 15(1), 225-242, 2018.

[23] https://www.mgm.gov.tr/veridegerlendirme/gunderece.aspx?g=yillik\&m=06-00\&y=2019\&a=05\#sfB (05.04.2020)

[24] Turkish Standardization Instution, 2008. TS 825 Thermal Insulation Requirements in Buildings. Ankara, Turkey: TSE.

[25] American Society of Heating, Refrigerating and AirConditioning Engineers, 2017. Thermal Environment Conditions for Human Occupancy (Standard 55). Atlanta, GA: ASHRAE.

[26] DF Robots, MG811, Carbon dioxide Sensor Datasheet, Retrieved from: https://wiki.dfrobot.com/CO2 Sensor SKU SEN0159\#t arget 0 15.10.2020. 
[27] DF Robots, DHT22, Temperature \& Relative Humidity Sensor Datasheet, Retrieved from: https://wiki.dfrobot.com/DHT22 Temperature and hu midity module SKU SEN0137 15.10.2020.

[28] SparkFun Electronics, HC - SR04, Ultrasonic Ranging Module Datasheet, Retrieved from: https://www.digikey.com/htmldatasheets/production/ 1979760/0/0/1/hc-sr04.html 15.10.2020.

[29] Turhan, C., Kazanazmaz, T., Uygun, I. E., Ekmen, K. E. and Akkurt, G. G., "Comparative study of a building energy performance software (KEP-IYTE-ESS) and ANNbased building heat load estimation", Energy and Buildings, 85, 115-125, 2014.

[30] Turhan, C., Simani, S., Zajic, I. and Akkurt, G. G., "Performance Analysis of Data-Driven and Model-Based Control Strategies Applied to a Thermal Unit Model", Energies, 10(1), 67, 2017.

[31] Mathworks, MATLAB, 2019.

[32] European Committee for Standardization, 2007. EN 15521-Indoor Environmental Input Parameters for Design and Assessment of Energy Performance of Buildings - Addressing Indoor Air Quality, Thermal Environment, Lighting and Acoustics. Brussels, Belgium: CEN.

[33] European Committee for Standardization, 2009. EN16798-Energy performance of buildings - Ventilation for buildings - Part 1. Brussels, Belgium: CEN.

[34] Charles, K. E. and Veitch, A. J., "Environmental Satisfaction in Open-Plan Environments: 2. Effects of Workstation Size, Partition Height and Windows". Ontario, Canada: IRC, 2002.

[35] Turhan, C., "Comparison of Indoor Air Temperature and Operative Temperature-Driven HVAC systems by Means of Thermal Comfort and Energy Consumption", Muğla Journal of Science and Technology, 6, 156-173, 2020. 